PALEO

Revue d'archéologie préhistorique

$24 \mid 2013$

Varia

\title{
Two newly identified Mousterian human rib fragments from Combe-Grenal (Domme, France)
}

Deux nouveaux fragments moustériens de côtes humaines identifiés à CombeGrenal (Domme, France)

Asier Gómez-Olivencia, María Dolores Garralda, Bernard Vandermeersch, Stéphane Madelaine, Juan-Luis Arsuaga and Bruno Maureille

\section{CpenEdition}

\section{Journals}

Electronic version

URL: http://journals.openedition.org/paleo/2653

DOI: $10.4000 /$ paleo.2653

ISSN: 2101-0420

\section{Publisher}

SAMRA

Printed version

Date of publication: 15 December 2013

Number of pages: 229-234

ISSN: 1145-3370

\section{Electronic reference}

Asier Gómez-Olivencia, María Dolores Garralda, Bernard Vandermeersch, Stéphane Madelaine, JuanLuis Arsuaga and Bruno Maureille, "Two newly identified Mousterian human rib fragments from Combe-Grenal (Domme, France) », PALEO [Online], 24 | 2013, Online since 17 April 2014, connection on 07 July 2020. URL : http://journals.openedition.org/paleo/2653 ; DOI : https://doi.org/10.4000/paleo. 2653

This text was automatically generated on 7 July 2020 .

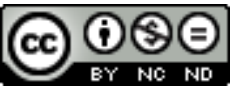

PALEO est mis à disposition selon les termes de la licence Creative Commons Attribution - Pas d'Utilisation Commerciale - Pas de Modification 4.0 International. 


\title{
Two newly identified Mousterian human rib fragments from Combe-Grenal (Domme, France)
}

\author{
Deux nouveaux fragments moustériens de côtes humaines identifiés à Combe- \\ Grenal (Domme, France)
}

Asier Gómez-Olivencia, María Dolores Garralda, Bernard Vandermeersch, Stéphane Madelaine, Juan-Luis Arsuaga and Bruno Maureille

Thanks to the Musée National de Préhistoire and its director J.-J. Cleyet-Merle for making the study of this material possible. Thanks also to A. Froment and P. Mennecier for the permission to access the modern human collections at the MNHN (Muséum national d'Histoire naturelle), and to V. Laborde and A. Fort for technical assistance. Thanks to J. Radovčić for the access to the Krapina Neandertal remains and to R.G. Franciscus, to Y. Onl and to L. Eaves for fruitful discussions. Ph. Jugie kindly made one of the photographs. R. Quam kindly revised the English. Thanks to the reviewers for their comments that have improved this work. Thanks to Bordeaux 1 University and the project Transitions convention 20051403003AB de la Région Aquitaine for financial support (MDG, BM). AGO has a Marie Curie-IEF research fellowship. AGO and JLA are supported by the Spanish Ministerio de Economía y Competitividad (project CGL2012-38434c03-01).

\section{Introduction}

1 The archaeological site of Combe-Grenal (C-G) is located close to the town of Domme and the Dordogne valley, in the south-west of France (for a complete account of this site see Garralda and Vandermeersch, 2000 and Maureille et al. 2009-2010). C-G is a rock shelter with a long and complex stratigraphy of over $13 \mathrm{~m}$. This site was inhabited by different human groups between marine isotopic stages (MIS) 6-3. The stratigraphy of Bordes' excavations has been divided into 64 levels, that have been attributed to either the late or «Meridional Acheulian » (levels 64 to 56) and to Mousterian (levels 55 to 1). This site has yielded many human fossil remains, mostly from the excavations of $F$. 
Bordes. The oldest human remain discovered in the administrative region of Aquitaine was found at this site : it was a lower right deciduous incisor which was found in level 60 (Maureille et al. 2009-2010), estimated to date to the last third of MIS 6 (about $130 \mathrm{ky}$ BP). Additional Neandertal remains from the site include an incomplete tooth from level 39, a fragment of frontal bone from level 35, and 24 cranial and postcranial specimens from level 25 (Garralda and Vandermeersch 2000). Four additional fossil remains found in D. and E. Peyrony's collection are also likely from Level 25 (or maybe slightly older ; Garralda and Vandermeersch 2000). Levels 35 and 25 were attributed to the isotopic stage 4 (Guadelli and Laville 1990). Most of the fossil remains (i.e. those from level 25) are tentatively dated chronologically from around 75/65 ky BP. According to the palaeo-environmental data, the climate at this time was intensely cold and generally dry. Some of the fossil remains show anthropogenic marks (Le Mort 1989 ; Garralda and Vandermeersch 2000 ; Garralda 2008, 2009 ; Garralda et al. 2005).

\section{1 - New remains from Combe-Grenal}

The revision of the faunal remains from the site of Combe-Grenal has resulted in the identification of two human rib fragments from level 25 (Bordes' excavations). These two remains constitute the 32nd and 33rd human remains from the Combe-Grenal collection (and thus are named Combe-Grenal 32 and Combe-Grenal 33) and are described below (see also Tables 1 and 2) and depicted in Figure 1. Both fragments are physically labelled with black ink. Due to their small size these remains are not taxinomically (see Tardieu 2011) diagnostic. However, a Neandertal attribution remains the simplest hypothesis based on the finding of several other bones and teeth with clear Neandertal affinities within a Mousterian cultural context and a chronology of around 75-65 ky BP within the same level (i.e., level 25) where these two remains have been found.

Table 1 - State of preservation of the two costal fragments from Combe-Grenal. $C=$ complete or virtually complete $; \mathrm{P}=$ partially preserved.

\begin{tabular}{|l|c|c|c|c|c|c|c|c|c|c|}
\hline \multicolumn{1}{|c|}{ Label } & $\begin{array}{c}\text { Physical } \\
\text { label }\end{array}$ & $\begin{array}{c}\text { Rib } \\
\text { anatomical } \\
\text { position } \\
\left(\mathbf{n}^{\circ}\right)\end{array}$ & Side & Head & Neck & Tubercle & Shaft & $\begin{array}{c}\text { Posterior } \\
\text { angle }\end{array}$ & Shaft & $\begin{array}{c}\text { Sternal } \\
\text { end }\end{array}$ \\
\hline $\begin{array}{l}\text { Combe- } \\
\text { Grenal 32 }\end{array}$ & C-G N & 1 & R & & C & C & P & N/A & & \\
\hline $\begin{array}{l}\text { Combe- } \\
\text { Grenal 33 }\end{array}$ & C-G G 4 N & $8-9$ & R & C & C & C & P & & & \\
\hline
\end{tabular}


Table 2 - Descriptive measurements of the two costal fragments from Combe-Grenal. Variable descriptions in Gómez-Olivencia et al. (2010).

\begin{tabular}{|l|c|c|}
\hline Label & $\begin{array}{c}\text { Combe-Grenal } \\
\mathbf{3 2}\end{array}$ & $\begin{array}{c}\text { Combe-Grenal } \\
\mathbf{3 3}\end{array}$ \\
\hline Physical label & C-G N & C-G G 4 N \\
\hline Rib anatomical position ( $\left.\mathrm{n}^{\circ}\right)$ & 1 & $8-9$ \\
\hline Side & $\mathrm{R}$ & $\mathrm{R}$ \\
\hline Oa-Preserved length & 48.4 & 41.3 \\
\hline Ob-Preserved external arc & 66.0 & 42.0 \\
\hline $\begin{array}{l}\text { Oc-Preserved external arc ventral to } \\
\text { the tubercle }\end{array}$ & 38.0 & 20.0 \\
\hline Od-Preserved internal arc & 43.0 & 31.0 \\
\hline
\end{tabular}

3 Within the C-G human sample from level 25 Garralda and Vandermeersch (2000) have indicated the presence of at least two children of ca. 7 years of age-at-death, two adolescents (one of around 12 years and a second one of around 14-15 years of age-atdeath, and several adult individuals some of which are young or middle age ( $<40$ years) while others would be older. Although the MNI for the adults has not been calculated yet (Garralda and Vandermeersch 2000) we have been able to distinguish that adults of different ages-at-death are represented in the collection based on the dental wear. The new costal remains are important because they are the first human rib remains identified in the collection.

\section{Combe-Grenal 32 (Inventory number : MNP 1965-3-28) : Fragment of a right first rib.}

4 This specimen was found by one of us (SM) on 04/11/2009 and it is labelled «C-G N » (Combe-Grenal, layer $\mathrm{N}$-also known as level 25). This fragment, with a maximum preserved length of $48.4 \mathrm{~mm}$ preserves most of the neck $(\sim 29 \mathrm{~mm})$, the articular tubercle and a small part of the shaft $(\sim 40 \mathrm{~mm})$ which does not reach neither of the subclavian grooves. Recent erosion on the neck close to the articular tubercle and on the most ventral edge of the latter has exposed the trabecular bone. Following the modern human developmental pattern (see Ríos and Cardoso 2009) the complete fusion of the articular tubercle epiphysis indicates that this rib belonged to an individual in late adolescence or in its adulthood, with a minimum age-at-death of 14 years, if this rib belonged to a female, or 17 years, if it belonged to a male, 
Figure 1 - New rib remains from Combe-Grenal.

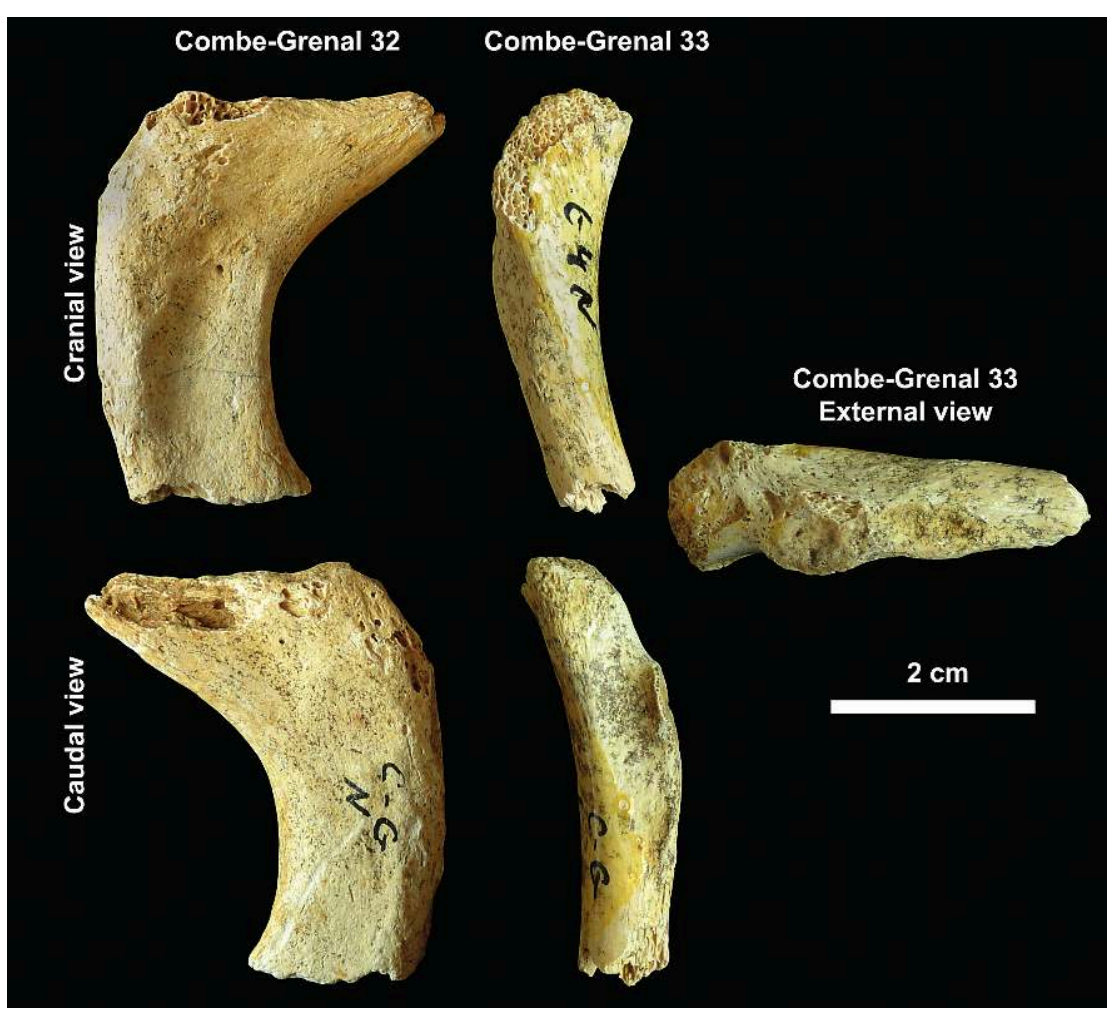

5 The preliminary analysis has identified a total of 13 definite cutmarks and two additional possible ones on the Combe-Grenal 32 first rib. On the cranial surface of this specimen, close to the internal border and the sternal end of the bone, there are nine short cutmarks. From distal to proximal, the first four cutmarks are deep and almost parallel to the internal border. The remaining five cutmarks are shorter, less marked and more perpendicular to the border. Three very short vertical cutmarks are also visible on the internal border, in a more proximal position than the previous ones. Finally, a tenth long and smooth cutmark is perpendicular to the external border and is located just between the head and the tubercle, with two shorter possible cutmarks parallel to it and closer to the external edge of the neck of the rib (see Figure 2). 
Figure 2 - First rib Combe-Grenal 32 in cranial view in which the different cutmarks are shown. Red arrows indicate cutmarks on the internal edge of the rib. The macrophotograph of the first rib courtesy of Ph. Jugie (๑ MNP Les Eyzies).

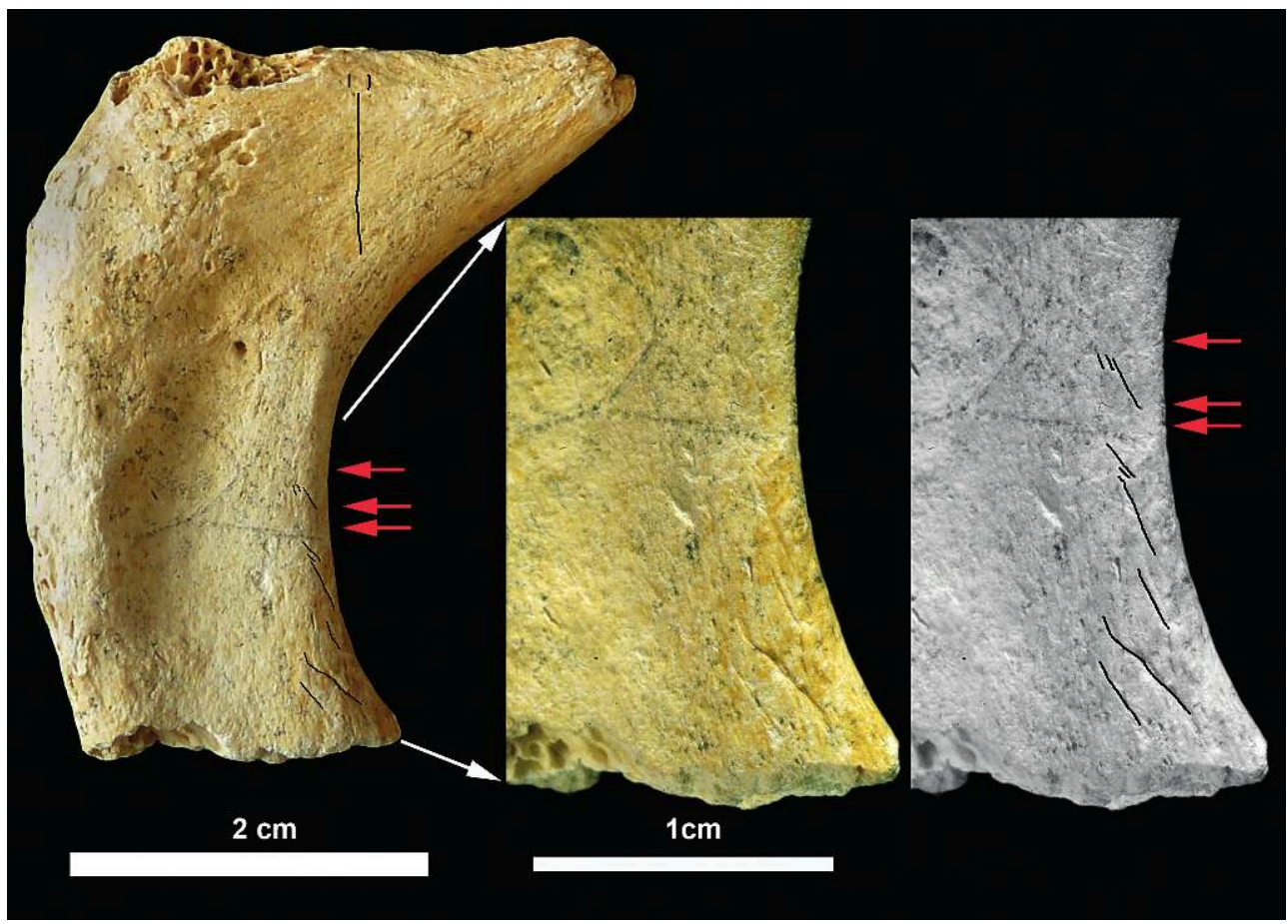

6 The only standard linear measurement that can be taken is the tubercle horizontal diameter (THD ; see Gómez-Olivencia et al. 2010). With a value of 19.2, this specimen is closer to the Neandertals of Kebara 2 and Regourdou 1, and above the specimens from Krapina. Compared to a modern human comparative sample, it is closer to the male mean rather than to the female mean (see Table 3).

Table 3 - Values of the tuberculo horizontal diameter (THD) of the first rib of Combe-Grenal compared to other Neandertal specimens and to a modern human comparative sample. $a 1$ : This study ; 2 : Gómez-Olivencia et al. 2010 ; 3 : Gómez-Olivencia et al. in preparation. b Estimated value. c Mean $\pm S D(\min -\max ) \mathrm{n}$.

\begin{tabular}{|l|l|c|l|c}
\hline \multicolumn{1}{|c|}{ Species } & \multicolumn{1}{|c|}{ Specimen } & Side & \multicolumn{1}{|c|}{$\begin{array}{c}\text { Tuberculo horizontal } \\
\text { diameter }\end{array}$} & Source $^{\mathrm{a}}$ \\
\hline $\begin{array}{l}\text { Homo } \\
\text { neanderthalensis }\end{array}$ & Combe-Grenal 32 & $\mathrm{R}$ & 19.2 & 1 \\
\hline & Kebara 2 & $\mathrm{R}$ & 19.8 & 2 \\
\hline & & $\mathrm{L}$ & 19.4 & 2 \\
\hline & Krapina 117.2 & $\mathrm{R}$ & 17.1 & 2 \\
\hline & Krapina 117.3 & $\mathrm{R}$ & $(16.5)^{\mathrm{b}}$ & 2 \\
\hline & Krapina 118.2 & $\mathrm{R}$ & 15.2 & 2 \\
\hline & Krapina 117.1 & $\mathrm{L}$ & 15.4 & 2 \\
\hline & Regourdou 1 & $\mathrm{R}$ & 18.4 & 3 \\
\hline & $\begin{array}{l}\text { Kuroamerican } \\
\text { Homo sapiens }\end{array}$ & $\mathrm{R}$ & $\begin{array}{l}17.08 \pm 1.63(12.9-19.8) \\
\mathrm{n}=33\end{array}$ & 2 \\
\hline & $\begin{array}{l}\text { Euroamerican } \\
\text { females }\end{array}$ & $\mathrm{R}$ & $\begin{array}{l}15.36 \pm 1.82(11.8-18.7) \\
\mathrm{n}=32\end{array}$ & 2 \\
\hline & & & 3 \\
\hline
\end{tabular}




\section{Combe-Grenal 33 (Inventory number : MNP 1965-3-29) : Fragment of a lower mid-thoracic rib.}

7 This specimen was found by one of us (AGO) on 16/02/2012 and labelled «C-G G 4 N" (Combe-Grenal, square $\mathrm{G} 4$, layer $\mathrm{N}-a$ also known as level 25). This specimen preserves the head, the neck, both the articular and non-articular tubercles and a fragment of the shaft vertebral to the posterior angle. It shows erosion on the head and on the cranial end of the articular tubercle. The absence of fusion of all the secondary epiphyses (head, articular tubercle and non-articular tubercle) suggests that this rib belonged to an immature individual with maximum ages-at-death of 16 years, if it belonged to a female, and of 19 years if it belonged to a male (following Ríos and Cardoso 2009 - Table 7). The relatively short and cranio-caudally elongated morphology of the neck suggests that it is a lower mid-thoracic rib, most likely a 9th (or an 8th). The presence of a secondary ossification area for the non-articular tubercle (present in only $12 \%$ of the 10th ribs of modern populations) makes it unlikely that it is a 10th rib (see Figure 3). Additional standard measurements are provided in Table 4.

Figure 3 - Comparison of Combe-Grenal 33 (a) with the 9th rib of the individual 29664 (13 year-old male) from MNHN of Paris (b).

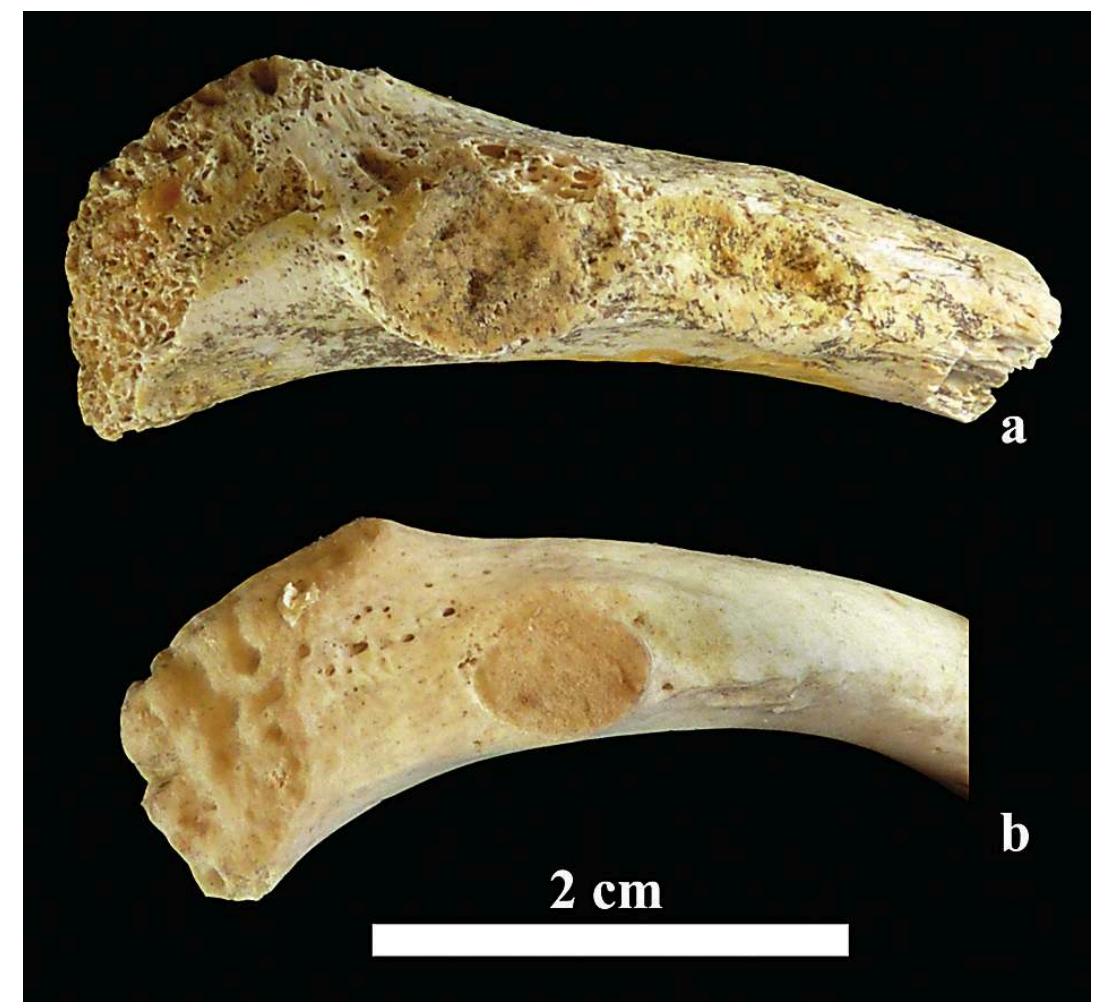


Table 4 - Raw dimensions ( $\mathrm{mm}$ ) of the Combe-Grenal 33 lower mid-thoracic rib (Values in parentheses are estimated). Variable descriptions in Gómez-Olivencia et al. (2010).

\begin{tabular}{|c|c|c|}
\hline \multicolumn{2}{|c|}{ Variable $^{*}$} & C-G G 4 N \\
\cline { 3 - 3 } & & $\mathbf{8 - 9}$ \\
\cline { 3 - 3 } & & $\mathbf{R}$ \\
\hline $4 \mathrm{a}$ & Head cranio caudal diameter (HCCD) & 13.5 \\
\hline $5 \mathrm{a}$ & Total neck length (TNL) & 23.5 \\
\hline 6 & Neck minimum cranio-caudal diameter (NMnCCD) & $(12.5)$ \\
\hline 7 & Neck thickness (NTh) & 8.1 \\
\hline 8 & Articular tubercle height (ATH) & 7.9 \\
\hline 9 & Articular tubercle width (ATW) & 8.5 \\
\hline 15 & Shaft maximum diameter at dorsal end (DSMxD) & 8.6 \\
\hline 16 & Shaft minimum diameter at dorsal end (DSMnD) & 7.5 \\
\hline
\end{tabular}

\section{2 - Summary and conclusions}

8 In this paper two new costal remains from level 25 at Combe-Grenal are described. One of them is a fragment of a right first rib that most likely belonged to an adult individual while the second is a fragment of lower mid-thoracic (possibly 8th or 9th) rib that most likely belonged to an adolescent individual. These ribs are the first human costal elements to be distinguished at the C-G collection and expand the anatomical representation of the elements found in this site. However, these two fragments do not increase the number of individuals represented in the collection. In fact, C-G 32 likely belonged to one of the adults while C-G 33 can likely be assigned to one of the two adolescents. The preliminary bone surface analysis has identified several cutmarks on the cranial and internal surface of the first rib Combe-Grenal 32. Similar post-mortem anthropic manipulation have been demonstrated on different elements from the same layer (Le Mort 1989 ; Garralda and Vandermeersch 2000 ; Garralda 2008, 2009 ; Garralda et al. 2005).

Due to their metameric nature and inherent fragility, ribs and vertebrae are difficult to identify to an exact taxinomic and anatomical level. However the reappraisal of the faunal remains can result in the identification of human remains. In fact, a classic example of this is the revision of the Krapina remains done by Tim D. White that significantly increased the number of human costal remains identified (Monge et al. 2013). A more recent example is the revision of the faunal remains of the Regourdou site that has yielded numerous new costal (and vertebral) remains belonging to the Regourdou 1 Neandertal (Maureille et al., in preparation). The efforts in this direction together with the revision of other costal remains (Franciscus and Churchill 2002; Gómez-Olivencia et al. 2009, in preparation) are providing new information on the thorax morphology of Neandertals, and additional efforts in other collections will likely result in interesting findings. 


\section{BIBLIOGRAPHY}

FRANCISCUS R.G. et CHURCHILL S.E. 2002 - The costal skeleton of Shanidar 3 and a reappraisal of Neandertal thoracic morphology. Journal of Human Evolution $n^{\circ}$ 42, 303-356.

GARRALDA M. D. 2008 - Les Néandertaliens : D’autres gestes envers les défunts. In : Vandermeersch B., Cleyet-Merle J.J., Jaubert J., Maureille B. et Turq A. (Coords.) Première Humanité : Gestes funéraires des Néandertaliens. Réunion des Musées Nationaux, Paris, 42-51. GARRALDA M. D. 2009 - Neandertales y manipulación de cadáveres. Estudios de Antropología Biológica, XIV, 601-628.

GARRALDA M.D. et VANDERMEERSCH B. 2000 - Les Néandertaliens de la grotte de Combe-Grenal (Domme, Dordogne, France). Paleo no 12, 213-259.

GARRALDA M. D., GIACOBINI G. et VANDERMEERSCH B. 2005 - Cut marks on the Neandertals from Combe-Grenal and Marillac (France). A SEM analysis. Anthropologie, XLIII/2-3, 251-271.

GÓMEZ-OLIVENCIA A., CARRETERO J.M., LORENZO C., ARSUAGA J.L., BERMÚDEZ DE CASTRO J.M. et CARBONELL E. 2010 - The costal skeleton of Homo antecessor : preliminary results. Journal of Human Evolution nº 59, 620-640.

GÓMEZ-OLIVENCIA A., EAVES-JOHNSON K.L., FRANCISCUS, R.G., CARRETERO J.M. et ARSUAGA J.L. 2009 - Kebara 2 : new insights regarding the most complete Neandertal thorax. Journal of Human Evolution nำ 57, 75-90.

GUADELLI J.-L. et LAVILLE H. 1990 - L'environnement climatique de la fin du Moustérien à Combe-Grenal et à Camiac. Confrontation des données naturalistes et implications. In : C. Farizy (Ed.), Paléolithique moyen récent et Paléolithique supérieur ancien en Europe. Mém. du Musée de Préhistoire d'Ile de France, p. 43-48.

LE MORT F. 1989. Traces de décharnement sur les ossements néandertaliens de Combe-Grenal (Dordogne). Bulletin de la Société Préhistorique Française no 86(3), 79-87.

MAUREILLE B., GARRALDA M.D., MADELAINE S., TURQ A. et VANDERMEERSCH B. 2009-2010 - Le plus ancien enfant d'Aquitaine : Combe-Grenal 31 (Domme, France). Paleo no 21, 189-202.

MONGE J., KRICUN M., RADOVČIĆ J., RADOVČIĆ D., MANN A., FRAYER D. W. 2013 - Fibrous Dysplasia in a 120,000 Year Old Neandertal from Krapina, Croatia. PLoS ONE 8(6) : e64539. doi : 10.1371/journal.pone.0064539

RÍOS L. et CARDOSO F.V. 2009 - Age estimation from stages of union of the vertebral epiphyses of the ribs. American Journal of Physical Anthropology no 140, 265-274.

TARDIEU C. 2011 - La bonne orthographe du mot taxinomie : un concept important dont l'orthographe est malmenée. Paleo, $n^{\circ}$ 22, 331-334.

\section{ABSTRACTS}

This paper presents the discovery and study of two new fossil human remains from the Mousterian site of Combe-Grenal located in the commune of Domme in Dordogne. These two fragments are from ribs and they have been found in level 25 (Bordes' excavation; Quina type Mousterian). One of them is a fragment of an adult right first rib. The second is a fragment of an adolescent lower mid-thoracic rib (possibly the 8th or 9th). Although none of these fragments 
have clear Neandertal traits due to their preservation state, they are nevertheless the first elements from the human trunk identified at Combe-Grenal. Therefore, they increase the diversity of the known bony parts found at this site. Nonetheless, the minimum number of individuals (MNI) is unchanged. The adult first rib shows traces of post-mortem anthropic manipulations.

Cet article présente la découverte et l'étude de deux nouveaux restes humains provenant du site moustérien de Combe-Grenal situé sur la commune de Domme en Dordogne. Il s'agit de deux fragments de côtes mis au jour dans la couche 25 des fouilles Bordes qui livre du Moustérien de type Quina. L'un d'eux est certainement un fragment de la première côte droite d'un adulte. Le second est un fragment d'une côte de rang élevé (8e ou 9e) d'un adolescent. Même si, en raison de leur état de conservation, aucune de ces pièces ne montre de trait dérivé néandertalien, elles représentent les premiers éléments appartenant au tronc humain découverts dans le site et augmentent ainsi la diversité des éléments osseux connus. Notons enfin que le NMI ne change pas. La première côte adulte montre des traces de manipulations post-mortem anthropiques. Néandertalien, Combe-Grenal, Moustérien, côte

INDEX

Keywords: Neandertal, Combe-Grenal, Mousterian, rib

\section{AUTHORS}

\section{ASIER GÓMEZ-OLIVENCIA}

Équipe de Paléontologie Humaine, CNRS, UMR 7194, Département de Préhistoire du Muséum national d'Histoire naturelle, 43 rue Buffon (Bâtiment 140) FR-75005 Paris agomezolivencia@mnhn.fr PAVE Research Group, Division of Biological Anthropology, Department of Archaeology and Anthropology, University of Cambridge, Pembroke Street, Cambridge CB2 3DZ, UK. Centro UCM-ISCIII de Investigación sobre Evolución y Comportamiento Humanos, Avda. Monforte de Lemos 5 (Pabellón 14), ES-28029 Madrid.

\section{MARÍA DOLORES GARRALDA}

U. D. de Antropología Física. Facultad de Biología. Universidad Complutense de Madrid. Ciudad Universitaria. ES-28040 Madrid - mdgarral@bio.ucm.es Universitẻ Bordeaux 1, CNRS, MCC, PACEA, UMR 5199, FR-33405 Talence cedex

\section{BERNARD VANDERMEERSCH}

Universitê Bordeaux 1, CNRS, MCC, PACEA, UMR 5199, FR-33405 Talence cedex bvanderm@bio.ucm.es

\section{STÉPHANE MADELAINE}

Musée national de Préhistoire, 1, rue du Musée FR-24620 Les Eyzies-de-Tayac stephane.madelaine@culture.gouv.fr Université Bordeaux 1, CNRS, MCC, PACEA, UMR 5199, FR-33405 Talence cedex 


\section{JUAN-LUIS ARSUAGA}

Centro UCM-ISCIII de Investigación sobre Evolución y Comportamiento Humanos, Avda.

Monforte de Lemos 5 (Pabellón 14), ES-28029 Madrid.

Departamento de Paleontología, Facultad de Ciencias Geológicas, Universidad Complutense de Madrid, Ciudad Universitaria s/n, ES-28040 Madrid - jlarsuaga@isciii.es

\section{BRUNO MAUREILLE}

Universitê Bordeaux 1, CNRS, MCC, PACEA, UMR 5199, FR-33405 Talence cedex b.maureille@pacea.u-bordeaux1.fr 